\title{
White mold intensity on common bean in response to plant density, irrigation frequency, grass mulching, Trichoderma spp., and fungicide
}

\author{
Trazilbo José de Paula Júnior ${ }^{1,4}$, Rogério Faria Vieira ${ }^{1,4}$, Paulo Roberto Ribeiro Rocha ${ }^{2}$, Alessandra Bernardes ${ }^{2}$, Édio \\ Luis Costa ${ }^{3}$, José Eustáquio Souza Carneiro ${ }^{2,4}$, Francisco Xavier Ribeiro do Vale ${ }^{2,4} \&$ Laércio Zambolim ${ }^{2,4}$
}

\begin{abstract}
${ }^{1}$ Empresa de Pesquisa Agropecuária de Minas Gerais (Epamig), Vila Gianetti 47, CEP 36570-000, Viçosa, MG, ${ }^{2}$ Universidade Federal de Viçosa, CEP 36570-000, Viçosa, MG; ${ }^{3}$ Epamig, Rodovia MG 424 - km 64, CEP 35701-000, Prudente de Morais, MG; ${ }^{4}$ Bolsista do CNPq.

Author for correspondence: Trazilbo José de Paula Júnior trazilbo@epamig.br

Data de chegada: 31/03/2008. Aceito para publicação em: 03/11/2008
\end{abstract}

\begin{abstract}
Paula Júnior, T.J.; Vieira, R.F.; Rocha, P.R.R.; Bernardes, A.; Costa, E.L.; Carneiro, J.E.S.; Vale, F.X.R.; Zambolim, L. White mold intensity on common bean in response to plant density, irrigation frequency, grass mulching, Trichoderma spp., and fungicide. Summa Phytopathologica, v.35, n.1, p.44-48, 2009

The purpose of this study was to evaluate the efficiency of integrated managements on white mold control on common bean. Initially, in vitro testing was made to assess the antagonism of 11 Trichoderma isolates against Sclerotinia sclerotiorum and to investigate fungicides (fluazinam and procymidone) inhibitory effects on those fungi. In two field experiments the following combinations were tested: irrigation frequencies (seven or 14 days), plant densities (six or 12 plants per meter), and three disease controls (untreated control, fungicide or Trichoderma spp.). In a third experiment plant densities were replaced by grass mulching treatments (with or without mulching). Fluazinam was applied at 45 and 55 days after emergence (DAE). The antagonists $T$.

harzianum (experiments 1 and 3 ) and T. stromatica (experiment 2) were applied through sprinkler irrigation at 10 and $25 \mathrm{DAE}$, respectively. Most of the Trichoderma spp. were effective against the pathogen in vitro. Fluazinam was more toxic than procymidone to both the pathogen and the antagonist. Fungicide applications increased yield between $32 \%$ and $41 \%$. In field one application of Trichoderma spp. did not reduce disease intensity and did not increase yield. The reduction from 12 to six plants per meter did not decrease yield, and disease severity diminished in one of the two experiments. It is concluded that of the strategies for white mold control just reduction of plant density and applications of fungicide were efficient.
\end{abstract}

Keywords: Phaseolus vulgaris, Sclerotinia sclerotiorum, McKinney index, incidence, yield.

\section{RESUMO}

Paula Júnior, T.J.; Vieira, R.F.; Rocha, P.R.R.; Bernardes, A.; Costa, E.L.; Carneiro, J.E.S.; Vale, F.X.R.; Zambolim, L. Intensidade do mofobranco em feijão em função de densidade de plantas, freqüência de irrigação, cobertura vegetal do solo, Trichoderma spp. e fungicida. Summa Phytopathologica, v.35, n.1, p.44-48, 2009

Objetivou-se estudar a eficácia de técnicas de manejo integrado no controle do mofo-branco em feijão. Inicialmente, foram feitos testes in vitro para avaliar o antagonismo de 11 isolados de Trichoderma contra Sclerotinia sclerotiorum e investigar os efeitos de fungicidas (fluazinam e procymidone) sobre esses fungos. Em dois ensaios de campo, foram testadas estas combinações: freqüências de irrigação (sete ou 14 dias), densidades de plantas (seis ou 12 por metro) e três controles da doença (testemunha sem controle, fungicida ou Trichoderma spp.). Em um terceiro ensaio, as densidades de plantas foram substituídas por tratamentos de cobertura vegetal do solo (com e sem). O fluazinam foi aplicado aos 45 e 55 dias após a emergência (DAE). Os antagonistas $T$. harzianum (experimentos 1 e 3 ) e T. stromatica (experimento 2) foram distribuídos via água de irrigação por aspersão aos 10 e 25 DAE, respectivamente. A maioria dos isolados do antagonista foi eficaz contra o patógeno in vitro. Fluazinam foi mais tóxico que procymidone ao patógeno e ao antagonista. $\mathrm{O}$ fungicida aumentou a produtividade entre $32 \%$ e $41 \%$. Uma aplicação de Trichoderma no campo não reduziu a intensidade da doença nem aumentou o rendimento de grãos. A redução de 12 para seis plantas por metro não diminuiu a produtividade, e a severidade da doença diminuiu em um ensaio. Conclui-se que das estratégias de controle do mofobranco apenas a redução da densidade de plantas e o uso de fungicida foram eficazes.

Palavras-chave adicionais: Phaseolus vulgaris, Sclerotinia sclerotiorum, índice de McKinney, incidência, produtividade.

Sclerotinia sclerotiorum (Lib.) de Bary is a ubiquitous and destructive pathogen, inciting disease on up to 408 plant species (3). Diseases induced by this pathogen is often referred to as white mold.

Approximately $35 \%$ of dry beans harvested in the State of Minas Gerais are produced in sprinkler irrigated areas during the fall-winter period. One of the most important diseases affecting dry beans in these areas is white mold. Several fungicides are active against this disease; among the most efficient ones is fluazinam $(17,23,24)$. An initial application is recommended during early bloom and, if the conditions continue to be favorable to white mold, an additional 
application may be necessary. Disease can also be reduced by practices that minimize excessive moisture beneath the plant canopy such as increasing distance between plants and less irrigation $(6,19)$. Moreover, grass mulching on the soil surface can reduces the number of apothecia formed on the soil $(6,16)$. The probable effects of grass mulching are: (a) failure of the stipes to reach the surface and develop apothecia and (b) reduction of light radiation under the mulch, essential for apothecial formation. More recently has increased the interest in using soil antagonistic microorganisms associated with sclerotia of $S$. sclerotiorum. Among them, Trichoderma has been one of the most intensively studied for this pathogen and other soilborne pathogens $(9,10)$. Commercial products containing conidia of Trichoderma are already available in Brazil for soilborne pathogens control. However, the efficacy of this antagonist in field for white mold control is not well known.

The objective with this study is to test an integrated management of white mold which include plant densities, irrigation frequencies, grass mulching, Trichoderma spp., and fungicide, during the fall-winter period at Zona da Mata, state of Minas Gerais, Brazil.

\section{MATERIALAND METHODS}

Tests were carried out at the Laboratory of Plant Pathology of the Federal University of Viçosa (UFV), located in Viçosa, Zona da Mata, state of Minas Gerais, to investigate the antagonism of Trichoderma against S. sclerotiorum in vitro. Sclerotia of the pathogen were collected from a contaminated bean field located at campus of the UFV. Six Trichoderma species from Epamig (Agricultural Research Institute of Minas Gerais State) and UFV collections and three isolates from $S$. sclerotiorum sclerotia collected from one contaminated bean field were used. In addition, a commercial product of T. harzianum and an isolate of $T$. stromatica (Table 1) were included in the tests. This latter species produces compact mycelial structures (stroma), which supposedly allows the fungus to persist longer in the soil. All isolates were kept stored at $4{ }^{\circ} \mathrm{C}$. Trichoderma spp. from the contaminated bean field were isolated using a selective medium containing rose Bengal as described by Elad et al. (5). They were incubated for three days at $25^{\circ} \mathrm{C}$. Then mycelium fragments were transferred to Petri dishes containing PDA and incubated for additional seven days at $25^{\circ} \mathrm{C}$. Sclerotia collected at the bean field were multiplied on autoclaved moist carrot for four to five weeks before being used in the tests.

One-cm length sclerotium and a mycelial-agar disc of the antagonist were placed on opposite sides of a Petri dish containing PDA. Ten replicates of each antagonist isolate were used. Inhibition of mycelial growing of S. sclerotiorum by Trichoderma spp. was evaluated according to Bell et al. (2). Furthermore, Petri dishes were digitally scanned and the fungi growth was estimated with the software QUANT (12).

Tests were also carried out to investigate the inhibitory effects of the fungicides fluazinam and procymidone against T. harzianum, $T$. stromatica and one isolate of S. sclerotiorum collected on the bean field. $250 \mathrm{ml}$ Erlenmeyer flasks containing PDA were autoclaved for 20 minutes at $120^{\circ} \mathrm{C}$. Before the distribution of the PDA into Petri dishes, the fungicides were poured into the flasks in five dilutions $\left(1000,100,10,1\right.$, and $\left.0.1 \mu \mathrm{L} \mathrm{L}^{-1}\right)$. The fungi were kept growing in the Petri dishes for seven days at $25^{\circ} \mathrm{C}$. After this period, mycelial discs from the growing edges ( $5 \mathrm{~mm}$ diameter) were transferred to the center of the Petri dishes with the diluted fungicides and kept at $25^{\circ} \mathrm{C}$. Five replications of each fungicide concentration were used. Colony diameter was measured every day during seven days using the software

\section{QUANT.}

Three experiments were carried out in an experimental area of the UFV, where symptoms of white mold on common beans have been observed during the winter season for at least 10 years. The soil has $53 \%$ clay, $24 \%$ silt, and $23 \%$ sand. The inoculum of S. sclerotiorum in this area is high and homogenously distributed.

Two experiments were conducted as a $2 \times 2 \times 3$ factorial: two overhead sprinkler irrigation frequencies (seven or 14 days apart), two plant densities (six or 12 plants per meter), and three white mold controls (untreated control, fluazinam, or Trichoderma spp.). Treatments were arranged in the randomized complete block design with four replicates. Water requirement of beans was calculated using a class A pan evaporation as described by Silveira \& Stone (20), considering an irrigation efficiency of $85 \%$. The coefficient of uniformity (CUC), that indicates the uniformity of water distribution, was $90 \%$. Cultivar Pérola (type III, carioca class) was sown in rows spaced $0.5 \mathrm{~m}$ apart. Plots of seven $3 \mathrm{~m}$-long rows were over-seeded (50\% more seeds than the planned plant densities) on May (end of fall) 2004 and densities were adjusted by thinning two weeks after planting. The fungicide fluazinam was applied by a backpack spray equipped with one cone nozzle delivering $667 \mathrm{~L} \mathrm{ha}^{-1}$ of fungicide solution. The applications were made at 45 (early bloom) and 55 days after emergence (DAE). Based on laboratory tests, two Trichoderma isolates were selected: T. harzianum was used in the experiment 1 and T. stromatica in the experiment 2.

The source of $T$. harzianum was the commercial product Trichodermil formulated as wettable powder $\left(1 \times 10^{8}\right.$ conidia $^{-1}, 8 \mathrm{~kg}$ $\left.\mathrm{ha}^{-1}\right)$. Product was used according to manufactory's instructions. It was applied over the plants and soil through sprinkler irrigation water at $10 \mathrm{DAE}$. For the $T$. stromatica treatment, two $5 \mathrm{~mm}$ diameter mycelial-agar disks of the growing fungus on Petri dishes with PDA were transferred to $200 \mathrm{~mL}$-Erlenmeyers flasks containing rice grains. After incubation for 15 days at $25{ }^{\circ} \mathrm{C}$ for conidia production, the inoculum was ground and immediately applied over plants and soil (1 x $10^{8}$ conidia $\mathrm{g}^{-1}$ ) as done for $T$. harzianum.

All plots received a basal fertilization: $24 \mathrm{~kg} \mathrm{ha}^{-1}$ of $\mathrm{N}, 37 \mathrm{~kg} \mathrm{ha}^{1}$ of $\mathrm{P}$, and $40 \mathrm{~kg} \mathrm{ha}^{-1}$ of $\mathrm{K}$. Ammonium sulfate application $\left(200 \mathrm{~kg} \mathrm{ha}^{-1}\right)$ as side dressing was performed $20 \mathrm{DAE}$, together with foliage application of molybdenum ( $80 \mathrm{~g} \mathrm{ha}^{-1}$ ) as sodium molybdate. Weeds were controlled by hand hoeing and with a commercial mixture of the herbicides fomesafen (250 g a.i. ha ${ }^{-1}$ ) and fluazifop-p-butyl (200 g a.i. $\left.\mathrm{ha}^{-1}\right)$. Insects were controlled, when needed, with monocrotophos $\left(400 \mathrm{~mL}\right.$ a.i. $\left.\mathrm{ha}^{-1}\right)$. The fungicide azoxystrobin $\left(60 \mathrm{~g}\right.$ a.i. $\left.\mathrm{ha}^{-1}\right)$ was applied once before flowering to protect beans against foliar diseases.

An area of $1.2 \mathrm{~m}^{2}$ (one internal row without $0.3 \mathrm{~m}$ of each side) in the plots was harvest separately at 90 DAE for white mold evaluation. Disease incidence was calculated as the percentage of plants with symptoms. Plants were rated for severity on a scale of $0,1,2,3$, and 4 representing $0,1-25 \%, 26-50 \%, 51-75 \%$, and $76-100 \%$ of stems, branches, and pods with disease symptoms, according to Hall \& Phillips (7). Severity scale was transformed in the McKinney index (MI) (14) according to this equation:

$$
\operatorname{MI}(\%)=\frac{\sum(\text { score } \times \text { number of plants with this score })}{(\text { total number of plants } \times \text { greater score })} \times 100
$$

In the third experiment the factor plant densities was replaced by grass mulching treatments (with or without mulching of Brachiaria decumbens). This species was sown on November 2004 in intercrop with maize. B. decumbens was desiccated with glyphosate ( $\left.1 \mathrm{~L} \mathrm{ha}^{-1}\right)$ two weeks before common bean has been planted. For the treatment 
without mulching, the grass was removed from the plots, and soil was prepared with a power rotary tiller. Fluazinam was applied the same way and dates described in the previous experiments. As a source of T. harzianum the commercial suspension Trichodermil formulated as concentrated suspension $\left(2 \times 10^{9}\right.$ conidia $\left.\mathrm{ml}^{-1}, 1 \mathrm{~L} \mathrm{ha}^{-1}\right)$ was used according to manufactory's instructions. It was applied over the plants and soil through irrigation water at 25 DAE. The cultivar Talismã (type III, carioca class) was sown on May 2005 in seven 3 m-long rows spaced $0.5 \mathrm{~m}$ apart.

With the plants harvested in the $1.2 \mathrm{~m}^{2}$ for disease evaluation, the weight of sclerotia larger than $2 \mathrm{~mm}$ was also taken. Yield data were estimated based on the weight of seeds with $12-13 \%$ moisture $(\mathrm{w} / \mathrm{w})$ harvested in $3.6 \mathrm{~m}^{2}$ (including the $1.2 \mathrm{~m}^{2}$ harvested for disease evaluation). Data were subjected to variance analysis using the software program SAEG; two means were compared by test F (1\% and $5 \%$ ) and three means by test of Tukey at the $5 \%$ level of probability.

\section{RESULTS AND DISCUSSION}

Eight Trichoderma isolates grew completely over the pathogen. Just the isolate number 4 had a poor performance (Table 1). For the following laboratory and field experiments the isolates $10(T$. harzianum) and 11 (T. stromatica) were selected. The growth inhibition of S. sclerotiorum after seven days, estimated by the software QUANT, was $78.2 \%$ for $T$. harzianum and $82.7 \%$ for $T$. stromatica (data not shown).

However, in field one application of Trichoderma did not reduce disease intensity and did not increase yield (Table 2). Trichoderma is more adapted to temperatures higher than $25^{\circ} \mathrm{C}(11)$. In this study, the average temperature was $17.1{ }^{\circ} \mathrm{C}$ in June, $15.4{ }^{\circ} \mathrm{C}$ in July, and $17.9^{\circ} \mathrm{C}$ in August. According to Hannusch \& Boland (8), surface colonization of petals by $T$. viride was most prevalent at $24{ }^{\circ} \mathrm{C} \mathrm{x}$ $100 \%$ relative humidity (RH) and $28{ }^{\circ} \mathrm{C}$ x $95 \%$ and $100 \% \mathrm{RH}$. On the other hand, colonization of petals and lesions by S. sclerotiorum only
Table 1. Antagonism of Trichoderma isolates on Sclerotinia sclerotiorum in

\begin{tabular}{lcc}
\hline Trichoderma isolates & Isolate number & Note \\
\hline Trichoderma sp. (bean field) & 1 & $\mathrm{~A}^{(1)}$ \\
Trichoderma sp. (bean field) & 2 & $\mathrm{~A}$ \\
Trichoderma sp. (bean field) & 3 & $\mathrm{~B}$ \\
Trichoderma sp. (Epamig collection) & 4 & $\mathrm{D}$ \\
Trichoderma sp. (Epamig collection) & 5 & $\mathrm{~A}$ \\
Trichoderma sp. (Epamig collection) & 6 & $\mathrm{~A}$ \\
Trichoderma sp. (UFV collection) & 7 & $\mathrm{~A}$ \\
Trichoderma sp. (UFV collection) & 8 & $\mathrm{~B}$ \\
Trichoderma sp. (UFV collection) & 9 & $\mathrm{~A}$ \\
Trichoderma stromatica & 10 & $\mathrm{~A}$ \\
Trichoderma harzianum (commercial) & 11 & $\mathrm{~A}$ \\
\hline
\end{tabular}

${ }^{(1)} \mathrm{A}$ - Complete growth of antagonist upon the pathogen; B - 2/3 growth of antagonist upon the pathogen; C - 1/2 growth of antagonist upon the pathogen; D - 1/3 growth of antagonist upon the pathogen.

occurred at $20{ }^{\circ} \mathrm{C}$ x $90 \%$ and $100 \% \mathrm{RH}$ and $24{ }^{\circ} \mathrm{C}$ x $95 \%$ RH. Lobo Junior \& Abreu (13) worked with four species of Trichoderma to evaluate their potential to inhibit mycelial growth of S. sclerotiorum at three temperatures. They concluded that the best results for the antagonists can occur outside the best temperature range for the pathogen. Thus, potential of Trichoderma spp. in environmental conditions that are marginal for disease can overestimate their potential efficacy. Another factor that may have influenced the efficacy of the antagonist in this research was the high disease pressure in field (white mold incidence varied from $79 \%$ to $98 \%$ ). Just one Trichoderma application was done in this research according to manufactory's instructions. Three or four applications (between 10 and 55 DAE) could improve the efficiency of this antagonist in field. The results of the laboratory tests suggest that fluazinam and the antagonist should not be used together in the field.

Table 2. Sclerotia weight, white mold intensity, and bean yield in response to fungicide and Trichoderma spp.

\begin{tabular}{|c|c|c|c|c|}
\hline Treatments & $\begin{array}{c}\text { Sclerotia } \\
\text { weight }^{1}(\mathrm{~g})\end{array}$ & $\begin{array}{c}\text { Incidence } \\
(\%)\end{array}$ & $\begin{array}{l}\text { McKinney } \\
\text { index }^{2}(\%)\end{array}$ & $\begin{array}{c}\text { Yield } \\
(\mathrm{kg} / \mathrm{ha})\end{array}$ \\
\hline \multicolumn{5}{|l|}{ Experiment 1} \\
\hline Trichoderma harzianum & $5.25 \mathrm{a}$ & $97.0 \mathrm{ab}$ & $64.9 \mathrm{a}$ & $1116 \mathrm{a}$ \\
\hline Fluazinam & $1.41 \mathrm{~b}$ & $92.1 \mathrm{~b}$ & $49.1 \mathrm{~b}$ & $1805 \mathrm{~b}$ \\
\hline $\mathrm{CV}(\%)$ & 45.05 & 6.63 & 17.04 & 23.4 \\
\hline Untreated control & $4.47 \mathrm{ab}$ & $95.6 \mathrm{a}$ & $62.5 \mathrm{a}$ & $997 \mathrm{a}$ \\
\hline Trichoderma stromaticum & $5.76 \mathrm{a}$ & $93.2 \mathrm{a}$ & $63.1 \mathrm{a}$ & $943 \mathrm{a}$ \\
\hline Fluazinam & $2.24 \mathrm{~b}$ & $93.2 \mathrm{a}$ & $47.9 \mathrm{~b}$ & $1684 \mathrm{~b}$ \\
\hline CV (\%) & 64.60 & 7.55 & 19.26 & 33.8 \\
\hline \multicolumn{5}{|l|}{ Experiment 3} \\
\hline $\mathrm{CV}(\%)$ & 65.82 & 18.73 & 20.54 & 14.2 \\
\hline
\end{tabular}

${ }^{1}$ Sclerotia larger than $2 \mathrm{~mm}$ attached to bean pods and stems and mixed to the seeds.

$2 \frac{\left.\sum \text { (score } \times \text { number of plants with this score }\right)}{\text { (total number of plants } \times \text { greater score })} \times 100$

${ }^{3}$ Means in the columns were compared by Tukey test (5\%). 


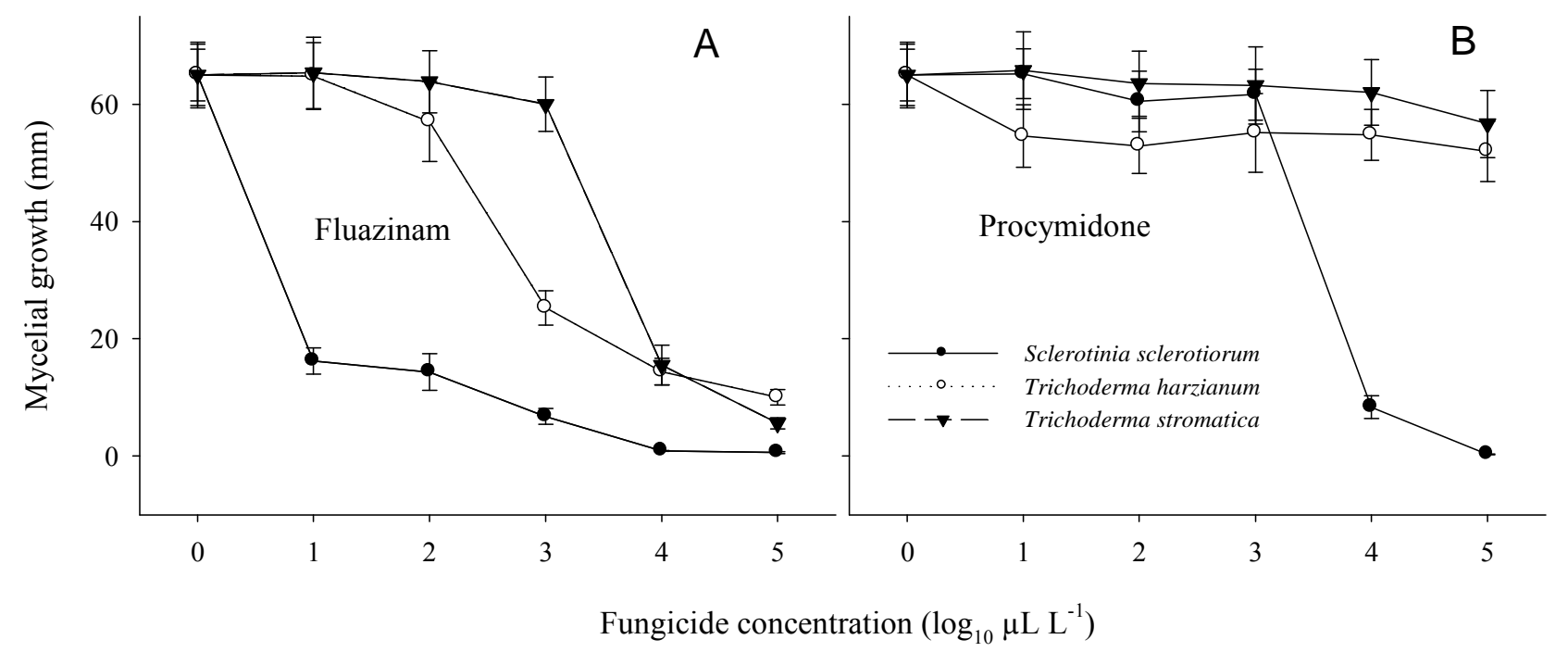

Figure 1. Effects of fluazinam (A) and procymidone (B) on the mycelial growth of Trichoderma spp. and Sclerotinia sclerotiorum

Fluazinam was more efficient than procymidone in reducing the mycelial growth of $S$. sclerotiorum at rates of $0.1,1$ and $10 \mu \mathrm{L} \mathrm{L}^{-1}$ (Fig. 1). Fluazinam at $0.1 \mu \mathrm{L} \mathrm{L}^{-1}$ reduced the mycelial growth from $65 \mathrm{~mm}$ (no fungicide) to $17 \mathrm{~mm}$, while procymidone did not affect it at this concentration. Complete inhibition of S. sclerotiorum growth occurred at $100 \mu \mathrm{L} \mathrm{L}^{-1}$ for fluazinam and $1000 \mu \mathrm{L} \mathrm{L}^{-1}$ for procymidone. Fluazinam was more toxic to the antagonists than procymidone, and the $T$. harzianum isolate was in general more sensitive than the $T$. stromatica isolate to the fungicides. Oliveira et al. (17) tested in vitro seven fungicides in relation to their action at different stages of $S$. sclerotiorum life cycle: mycelial growth, production of sclerotia, and myceliogenic and carpogenic germination of sclerotia. They found that fluazinam was more efficient than procymidone on inhibiting mycelial growth of S. sclerotiorum. Furthermore, those authors verified that fluazinam was more efficient than the other fungicides for fungus control in different stages. Because of these characteristics, fluazinam provides white mold control even when applied just on soil (24).

White mold intensity was severe in the three experiments, mainly in the experiments 1 and 2 (Table 2). The effects of irrigation frequencies, grass mulching treatments, and interactions of the factors on sclerotia weight, disease intensity, and bean yield were not significant, but the effects of white mold control treatments were significant $(\mathrm{P}<0.01)$ (Table 2). Plant densities was just significant $(\mathrm{P}$ $<0.01)$ for severity in the first experiment: the McKinney index was $55.3 \%$ with six plants per meter and $65.7 \%$ with 12 plants per meter. In the two experiments where plant densities were tested, this factor did not influence yield significantly (data not shown).

Fluazinam was very effective in reducing disease severity and the amount of sclerotia produced in the plant. Reduction of white mold incidence by fluazinam was only highly significant in the experiment 3. As a result of the disease reduction by the fungicide, yield was increased between $32 \%$ and $41 \%$.

Besides fungicide, just plant densities interfered on the disease severity, which was lower with six than with 12 plants per meter in one of the two experiments where plant densities were tested. In one of the two experiments conducted by Vieira et al. (25), there was a reduction of both incidence and severity of white mold when six plants instead of 12 plants per meter were used. High plant density reduces air circulation and trap moisture in the canopy, contributing to higher incidence and more severe white mold than low plant density
(22). Similarly to the results of this research, six plants per meter did not result in lower yield in the research of Vieira et al. (25). This density (equivalent to 120 thousand plants per hectare) correspond to half of the population recommended for common bean (1), which might cause a lower bean yield compared with 12 plants per meter in condition of absence of white mold on the field. Therefore, no yield reduction using lower plants population in field highly infested with S. sclerotiorum is an interesting result and implies a lower investment with seeds as well.

Unexpected rains during the experiments were probably the reason of the non-significant effect of irrigation frequencies. In 2004, they fell steadily until R7 phase of common beans (pod formation). In 2005 , they fell during the entire life cycle of beans, especially during the R6 (opening flowers) and R7 phases. Sun \& Yang (21) studied the effects of light, moisture, and temperature on apothecium production of S. sclerotiorum. Their results suggest that, before the canopy closes, high soil moisture is important for apothecium production. However, after canopy closure, the relative importance of soil moisture for apothecium production may be reduced due to the reduction in light intensity, and temperature becomes more important. In our experiments, rainfalls occurred until after plant closure, fact that helps to explain why there was no effect of irrigation frequencies.

Grass mulching did not reduce white mold disease intensity in this one-crop experiment. One possible explanation for that is the thin mulch layer $(1-3 \mathrm{~cm})$ formed by $B$. decumbens. According to Ferraz et al. (6), the effect of grass mulching was most pronounced with 6 and $9 \mathrm{~cm}$ of mulch, probably because that layer was wide enough to obstruct stipes to reach the surface and develop apothecia.

The results suggest that control of white mold with fungicide in areas with uniform and high infestation of sclerotia is profitable and consisting. The use of lower plant density should be encouraged in fields infested with sclerotia since this management do not increase production cost. In fact, it may reduce the costs with seeds, but a good weed control is necessary. Although fewer irrigations did not reduce white mold intensity in this research, the use of this strategy is recommended $(4,18)$, especially when a cultivar with a dense plant canopy is used (16). In a long-term strategy, there are indications that no-tillage is a better system than conventional tillage to reduce the risk with white mold $(15,22,26)$. Sclerotia kept near the top 2-3 cm of soil deteriorate within a year and those buried deeper in the soil 
have a higher rate of survival. Thus, a combination of proper crop rotation and no-tillage operation can reduce white mold intensity (22). Studies of factors that influence Trichoderma spp. performance on white mold control should be done in regions with different environmental conditions to better understand its potential.

In conclusion, fungicide is very effective for white mold control and increases yield substantially. In a condition of high disease intensity, reduction from 12 to six plants per meter helps to decrease white mold severity without influence on yield. Thin grass mulching and one application of Trichoderma spp. at 10 or 25 DAE do not influence both white mold intensity and yield.

\section{ACKNOWLEGEMENT}

To International Foundation for Science (IFS, Sweden), for support.

\section{REFERENCES}

1. Araújo, G.A.A.; Ferreira, A.C. de B. Manejo do solo e plantio. In: Vieira, C.; Paula Júnior, T.J.; Borém, A. (Ed.). Feijão. 2 ed. Viçosa: Editora UFV, 2006. p. 87-114.

2. Bell, D.K.; Wells, H.D.; Markham, C.R. In vitro antagonism of Trichoderma species against six fungal pathogens. Phytopathology, St. Paul, v.72, p. 379-382, 1982.

3. Bolland, G.J.; Hall, R. Index of plant hosts of Sclerotinia sclerotiorum. Canadian Journal of Plant Pathology, Ottawa, v.16, p. 93-108, 1994.

4. Canteri, M.G.; Pria, M.D.; Silva, O.C. da. Principais doenças fúngicas do feijoeiro: orientações de manejo econômico e ecológico. Ponta Grossa: UEPG, 1999.178 p.

5. Elad, Y.; Chet, I.; Henis, Y. A selective medium for improving quantitative isolation of Trichoderma spp. from soil. Phytoparasitica, Rehovot, v.9, p. 59-67, 1981.

6. Ferraz, L.C.L.; Café Filho, A.C.; Nasser, L.C.B.; Azevedo, J. Effects of soil moisture, organic matter and grass mulching on the carpogenic germination of sclerotia and infection of bean by Sclerotinia sclerotiorum. Plant Patholology, London, v.48, p. 77-82, 1999

7. Hall, R.; Phillips, L.G. Evaluation of parameters to assess resistance of white bean to white mold. Bean Improvement Cooperative Annual Report, East Lansing, v.39, p. 306-307, 1996.

8. Hannusch, D.J.; Boland, G.J. Influence of air temperature and relative humidity on biological control of white mold of bean (Sclerotinia sclerotiorum). Phytopathology, St. Paul, v.86, p. 156-162, 1996.

9. Hjeljord, L.; Tronsmo, A. Trichoderma and Gliocladium in biological control: an overview. In: Harman, G.E.; Kubicek, C.P. (Ed.). Trichoderma \& Gliocladium: enzymes, biological control and commercial applications. London: Taylor \& Francis, 1998. v.2, p. 131-151.

10. Huang, H.C.; Bremer, E.; Hynes, R.K.; Erickson, R.S. Foliar application of fungal biocontrol agents for the control of white mold of dry bean caused by Sclerotinia sclerotiorum. Biological Control, Amsterdam, v.18, p. 270-276, 2000.

11. Klein, D.; Everleigh, D.E. Ecology of Trichoderma. In: Kubicek,
C.P.; Harman, G.E. (Ed.). Trichoderma \& Gliocladium: enzymes, biological control and commercial applications. London: Taylor \& Francis, 1998. v.1, p. 57-74.

12. Liberato, J.R. Desenvolvimento e avaliação do software QUANT para quantificação de doenças de plantas por análises de imagens. 2003. p. 112. (Doutorado em Fitopatologia). Universidade Federal de Viçosa, Viçosa, MG.

13. Lobo Júnior, M.; Abreu, M.S. de. Inibição do crescimento micelial de Sclerotinia sclerotiorum por metabólitos voláteis produzidos por alguns antagonistas em diferentes temperaturas e pH's. Ciência e Agrotecnologia, Lavras, v.24, p. 521-526, 2000

14. Mckinney, H.H. Influence of soil temperature and moisture on infection of wheat seedlings by Helminthosporium sativum. Journal Agricultural Research, Washington, v.26, p. 195-218, 1923

15. Mila, A.L.; Carriquiry, A.L.; Zhao, J.; Yang, X.B. Impact of management practices on prevalence of soybean sclerotinia stem rot in the north-central United States and on farmer's decisions under uncertainty. Plant Disease, St. Paul, v.87, p. 1048-1058, 2003.

16. Napoleão, R.; Café Filho, A.C.; Nasser, L.C.B.; Lopes, C.A.; Silva, H.R. Intensidade do mofo-branco do feijoeiro em plantio convencional e direto sob diferentes lâminas d'água. Fitopatologia Brasileira, Brasília, v.30, p. 374-379, 2005.

17. Oliveira, S.H.F.; Kimati, H.; Tofoli, J.G. Ação diferencial de fungicidas no ciclo de vida de Sclerotinia sclerotiorum do feijoeiro. Summa Phytopathologica, Jaboticabal, v.25, p. 256-261, 1999.

18. Paula Júnior, T.J.; Vieira, R.F.; Lobo Júnior, M.; Morandi, M.A.B.; Carneiro, J.E.S.; Zambolim, L. Manejo integrado do mofobranco do feijoeiro. Viçosa: Epamig, 2006. 48 p.

19. Schwartz, H.F.; Steadman, J.R. White mold. In: Schwartz, H.F.; Pastor-Corrales, M.A. (Ed.). Bean production problems in the tropics. Cali: CIAT, 1989. p. 211-230.

20. Stone, L.F.; Silva, S.C. Uso do tanque classe A no controle da irrigação do feijoeiro no sistema plantio direto. Pesquisa em Foco Embrapa Arroz e Feijão, Santo Antônio de Goiás, n.25, 1999. 2 p.

21. Sun, P.; Yang, X.B. Light, temperature, and moisture effects on apotehcium production of Sclerotinia sclerotiorum. Plant Disease, St. Paul, v.84, p. 1287-1293, 2000.

22. Tu, J.C. An integrated control of white mold (Sclerotinia sclerotiorum) of beans, with emphasis on recent advances in biological control. Botanical Bulletin of Academia Sinica, Taipei, v.38, p. 73-76, 1997.

23. Vieira, R.F.; Paula Júnior, T.J.; Peres, A.P.; Machado, J.C. Fungicidas via água de irrigação no controle do mofo-branco do feijoeiro e incidência do patógeno na semente. Fitopatologia Brasileira, Brasília, v.26, p. 770-773, 2001.

24. Vieira, R.F.; Pinto, C.M.F.; Paula Júnior, T.J. Chemigation with benomyl and fluazinam and their fungicidal effects in soil for white mold control on dry beans. Fitopatologia Brasileira, Brasília, v.28, p. 245-250, 2003.

25. Vieira, R.F., Pinto, C.M.F.; Paula Júnior, T.J. Fungicide, row widths and plant densities affecting white mold intensity. Bean Improvement Cooperative Annual Report, East Lansing, v.48, p. $128-129,2005$.

26. Workneh, F.; Yang, X.B. Prevalence of sclerotinia stem rot of soybeans in the North-Central United States in relation to tillage, climate, and latitudinal positions. Phytopathology, St. Paul, v. 90, p. $1375-1382,2000$. 